\title{
High-temperature study of basic ferric sulfate, $\mathrm{FeOHSO}_{4}$
}

\author{
Gennaro Ventruti ${ }^{1}$ (D) Giancarlo Della Ventura ${ }^{2,3}$ (D) Mario Alberto Gomez ${ }^{4}$ Giancarlo Capitani ${ }^{5} \cdot$ Marco Sbroscia $^{2}$. \\ Armida Sodo ${ }^{2}$
}

Received: 12 June 2020 / Accepted: 13 September 2020 / Published online: 1 October 2020

(c) The Author(s) 2020

\begin{abstract}
We report in this paper a new crystal-chemical study of synthetic basic ferric sulfate $\mathrm{FeOHSO}_{4}$. The structure solution performed by the Endeavour program, from new X-ray powder diffraction (XRPD) data, indicated that the correct space group of the monoclinic polytype of $\mathrm{FeOHSO}_{4}$ is $\mathrm{C2} / \mathrm{c}$. Selected Area Electron Diffraction (SAED) patterns are also consistent with this structure solution. The arrangement of $\mathrm{Fe}$ and $\mathrm{S}$ atoms, based on linear chains of $\mathrm{Fe}^{3+}$ octahedra cross-linked by $\mathrm{SO}_{4}$ tetrahedra, corresponds to that of the order/disorder (OD) family. The positions of the hydrogen atoms were located based on DFT calculations. IR and Raman spectra are presented and discussed according to this new structure model. The decomposition of $\mathrm{FeOHSO}_{4}$ during heating was further investigated by means of variable temperature XRPD, thermogravimetry, and differential thermal analysis as well as IR and Raman spectroscopies.
\end{abstract}

Keywords Sulfate $\cdot$ Crystal structure $\cdot$ Thermal stability $\cdot$ HT-FTIR $\cdot$ Raman

\section{Introduction}

The basic iron hydroxyl sulfate, $\mathrm{FeOHSO}_{4}$, has attracted in the last decades significant attention in many research fields such as environmental science, catalysis, electrochemistry, mineralogy, and soil science (Cheng and Demopoulos 2004; Fleming 2010; Xu et al. 2010; Reddy et al. 2009). It is also known to form during the thermal decomposition of hydrates

Electronic supplementary material The online version of this article (https://doi.org/10.1007/s00269-020-01113-7) contains supplementary material, which is available to authorized users.

Gennaro Ventruti

gennaro.ventruti@uniba.it

1 Dipartimento di Scienze della Terra e Geoambientali, Università di Bari, via Orabona, 4, 70125 Bari, Italy

2 Dipartimento di Scienze, Università Roma Tre, Largo S. Leonardo Murialdo 1, 00146 Rome, Italy

3 INFN-LNF, Frascati, Rome, Italy

4 Liaoning Engineering Research Center for Treatment and Recycling of Industrially Discharged Heavy Metals, Shenyang University of Chemical Technology, Shenyang 110142, China

5 Department of Earth and Environmental Sciences, University of Milano-Bicocca, Piazza della Scienza, 4, 20126 Milano, Italy of $\mathrm{Fe}^{2+}$ sulfate (e.g., Swamy and Prasad 1981; Pelovski et al. 1996) and other secondary iron-sulfate minerals (e.g., Ventruti et al. 2014, 2016). The crystal structure $\mathrm{FeOHSO}_{4}$ was solved by Johansson (1962) in the orthorhombic space group Pnma and described as consisting of linear chains of $\mathrm{Fe}^{3+}$ octahedra cross-linked by $\mathrm{SO}_{4}$ tetrahedra. More recently, Ventruti et al. (2005) demonstrated, based on the OD theory, that this compound may crystallize under two different polytypes. The first corresponds to the orthorhombic polytype reported by Johansson (1962). The second is a monoclinic form that was proposed by Ventruti et al. (2005) to have $P 2_{1} / c$ symmetry. The monoclinic polytype was later synthesized by Reddy et al. (2009), who demonstrated that this material has reversible exchange capabilities for $\mathrm{Li}$, and thus excellent electrochemical performance for energy storage applications. The formation of monoclinic $\mathrm{FeOHSO}_{4}$ was also observed as a by-product at elevated temperatures in the industrial pressure oxidation (POX) hydrothermal treatment of refractory gold ores (Fleming 2009, 2010; Adams 2016; Dutrizac and Jambor 2007). It has also been documented that during sub-microscopic gold or copper POX hydrothermal extraction, $\mathrm{FeOHSO}_{4}$ can incorporate up to $9.8-10 \mathrm{wt} \%$ of $\mathrm{AsO}_{4}$ substituting for $\mathrm{SO}_{4}$ in the structure (Dutrizac and Jambor 2007; Gomez et al. 2013; Paktunc et al. 2013). The solid solution of basic ferric sulfate (BFS) and basic ferric arsenate sulfate (BFAS) has shown promising features in the 
environmental remediation of arsenic from POX hydrothermal operations of $\mathrm{Au}$ and $\mathrm{Cu}$ (Swash and Monhemius 1994; Dutrizac and Jambor 2007; Gomez et al. 2011; Bruce et al. 2012; Paktunc et al. 2013). Paktunc et al. (2013) indicated that a residue from POX hydrothermal gold extraction was in the form of an iron hydroxy sulfate with a $5.42 \mathrm{wt} \%$ $\mathrm{AsO}_{4}$ content, and proposed it precipitated in a triclinic (I1) space group based on TEM-SAED investigation. It is worth noting that Transmission Electron Microscopy (TEM) may be used for sub-micron-sized samples to obtain an approximate structure model (e.g., Li and Sun 2017). However, if a sufficient amount of sample is available, structure refinement is better suited via powder X-ray diffraction because of the detrimental effects of dynamical scattering on electron diffraction intensities (e.g., Gemmi et al. 2010). Recently, good results have been obtained applying dynamical theory to electron diffraction structure refinement (e.g., Palatinus et al. 2017).

Thermal analyses and decomposition studies of $\mathrm{FeOHSO}_{4}$ (e.g., Mahapatra et al. 1990; Pelovski et al. 1996 and references therein), are present in the literature and have been aimed at characterizing the stability of this compound, the reaction pathway of its thermal decomposition and at investigating the environmental variables that control the process under temperature treatment. Although, in most cases, the investigations have been done by combining different techniques and methods (derivatographic, thermogravimetric, powder X-ray phase analysis, and Mössbauer spectroscopy), the results have been subjected to considerable controversy. The inconsistency of some of these results is mainly due to both the order-disorder (OD) character of the $\mathrm{FeOHSO}_{4}$ structure and to the difficult identification of possible intermediate unstable decomposition products, thus making the process complicated to follow in detail. Another source of uncertainties in the study of these compounds is the extremely complex and variable molecular state of sulfur for different experimental ( $\mathrm{RH}, \mathrm{pH}$, and $\mathrm{T})$ conditions.

Given the importance of these phases and close analogs (e.g., BFAS) in industrial processing/environmental compliance and potential energy applications, the present work was aimed at characterizing the structure of synthetic $\mathrm{FeOHSO}_{4}$ via XRPD and TEM-SAED techniques. Furthermore, we investigate the decomposition of $\mathrm{FeOHSO}_{4}$ during thermal treatment using a combination of in situ techniques.

\section{Experimental methods}

The $\mathrm{FeOHSO}_{4}$ monoclinic phase was prepared following the method described by Reddy et al. (2009). Accordingly, the starting product consisting of reagent-grade ferrous sulfate heptahydrate, $\mathrm{FeSO}_{4} \cdot 7 \mathrm{H}_{2} \mathrm{O}$, was ground in an agate mortar to a fine powder, transferred to an alumina boat, and dehydrated in the air at $280{ }^{\circ} \mathrm{C}$ for 7 days.

XRPD data were collected in reflection mode from room temperature (RT) to $900{ }^{\circ} \mathrm{C}$ using a Panalytical Empyrean diffractometer equipped with a PIXcel3D RTMS detector and an Anton Paar HTK1200N furnace. The sample was ground in an agate mortar, passed through a 400-mesh sieve, and loaded into an alumina sample holder. The sample was irradiated with X-rays generated by a copper long-fine focus tube operated at $40 \mathrm{kV}$ and $40 \mathrm{~mA}$. A $0.125^{\circ}$ divergence slit, a $0.25^{\circ}$ anti-scattering slit, and a Soller slit (0.02 rad) were mounted in the incident beam pathway. The diffracted beam pathway included a Ni filter, a Soller slit $(0.02 \mathrm{rad})$, and an anti-scatter blade $(7.5 \mathrm{~mm})$. XRPD data were collected in the angular range $3-70^{\circ}(2 \theta)$ using a virtual step scan of $0.026^{\circ}$ and a counting time of $360.0 \mathrm{~s} / \mathrm{step}$. The program ENDEAVOUR (Putz et al. 1999) was used for ab initio structure determination. The GSAS (Larson and Von Dreele 2000) software was used for the unit-cell parameter refinement, the Rietveld analysis of the structure, and the quantitative phase determination. DFT calculation using the CRYSTAL09 (Saunders et al. 2003) program package was used to locate the hydrogen position.

For transmission electron microscopy (TEM) observation, an aliquot of the untreated sample used for XRPD analyses was dispersed in isopropanol and ultrasonicated, and few microliters of the suspension were pipetted onto a holey-carbon, 300-mesh, Cu-grid. TEM observations were performed at the Department of Physical Sciences, Earth and Environment of the University of Siena with a Jeol JEM 2010 instrument. The instrument operates at $200 \mathrm{kV}$, and is equipped with an Oxford Link energy dispersive system (EDS) and an Olympus Tengra $2.3 \mathrm{k} \times 2.3 \mathrm{k} \times 14$-bit slowscan CCD camera. Semi-quantitative EDS analyses were obtained with the standardless method using the approximation of Cliff and Lorimer (1975).

Simultaneous thermal gravimetric analysis (TGA) and differential thermal analysis (DTA) were conducted in an $\mathrm{N}_{2}$ atmosphere (flow rate $60 \mathrm{~mL} / \mathrm{min}$ ) with an STA7200 analyzer (HITACHI). The powdered sample $(\sim 22 \mathrm{mg})$ was put into an alumina pan and heated from room temperature (RT) to $900{ }^{\circ} \mathrm{C}$ with a heating rate of $10{ }^{\circ} \mathrm{C} / \mathrm{min}$. Sintered $\alpha-\mathrm{Al}_{2} \mathrm{O}_{3}$ powder was the thermally inert reference material used. To simultaneously follow the evolution of the gaseous decomposition products over the temperature range investigated, the thermobalance was connected to a Fourier transform infrared (FTIR) spectrometer through a heated line. The balance adapter, the transfer line, and the FTIR gas cell were kept to about $220{ }^{\circ} \mathrm{C}$ to avoid possible condensation of the evolved gases. $\mathrm{N}_{2}$ was used as a carrier gas, because it is inert and difficult to ionize and will not interfere with the infrared spectra of the evolved product gases. 
FTIR spectra of the studied $\mathrm{FeOHSO}_{4}$ compound were collected with the conventional pelletized sample using a Nicolet iS50 spectrometer equipped with a Globar IR source and a $\mathrm{KBr}$ beamsplitter. In situ HT-FTIR measurements were done using pure mineral powders employing a Linkam T600 heating/freezing stage fitted in a Bruker Hyperion 3000 FTIR microscope attached to a Vertex $70 \mathrm{~V}$ optical bench and equipped with a 15X Schwarzschild objective and an MCT $\mathrm{N}_{2}$-cooled detector. The sample powder was finely dispersed on a $\mathrm{CaF}_{2}$ sample holder; the nominal resolution was set at $4 \mathrm{~cm}^{-1}$ and 128 spectra were co-added for both mineral and background. Although a few crystals were illuminated with a beam diameter of $30 \mu \mathrm{m}$, the signal in the principal $\mathrm{OH}$-stretching region was saturated, and thus, the dehydration of the sample was monitored using the combination band at $4470 \mathrm{~cm}^{-1}$ (see below).

Unpolarised Raman spectra were collected using a Labram Micro-Raman spectrometer by Horiba, equipped with an Olympus BX40 confocal microscope, and a Peltier cooled $(\sim 200 \mathrm{~K}) 1024 \times 256$ pixel CCD detector. Raman scattering was excited by a He-Ne laser at $632.8 \mathrm{~nm}$ (nominal output power $18 \mathrm{~mW}$ ). The system achieves the high contrast required for the rejection of the elastically scattered component by the use of edge filters. The backscattered light is dispersed by an 1800 line/mm grating, for a nominal resolution of $\sim 1 \mathrm{~cm}^{-1}$. In situ HT Raman spectra were collected by means of a Linkam T600 heating/freezing stage placed on the microscope sample holder.

\section{Results and discussion}

\section{RT X-ray structure solution and TEM analysis}

The XRPD pattern collected at RT for the studied sample (Fig. 1) was fully indexed using the well-known and popular indexing algorithm TREOR90 (Werner et al. 1985) yielding a monoclinic solution with approximate cell parameters (in A) $a \sim 7.39, b \sim 7.14, c \sim 7.39$, and $\beta\left(^{\circ}\right) \sim 120$. Subsequent Le Bail refinement was performed in GSAS to refine cell parameters and to extract diffraction lines. A small peak, likely corresponding to a residue of unreacted starting materials used in the synthesis, was observed at about $18^{\circ}(2 \theta)$. This impurity peak was excluded from the refinement. The resulting peak list was imported into Endeavour along with the contents of the unit cell to solve the structure. During the structure solution calculations, the Endeavour software matches the calculated diffraction pattern of each trial crystal structure to the experimental diffraction pattern. All atoms but the hydrogen of the hydroxyl group were successfully determined in the $C 2 / c$ space group. At this stage, the structure was refined by the Rietveld method using the GSAS program (Fig. 1). During the refinement, the isotropic

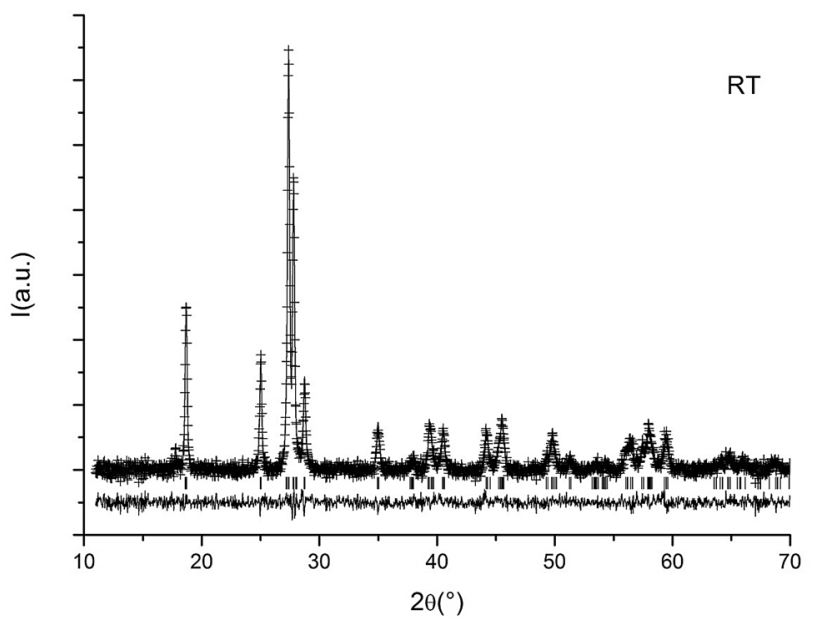

Fig. 1 Room-temperature X-ray powder pattern of the studied $\mathrm{FeOHSO}_{4}$ (cross symbols) sample. The calculated pattern (line) and the difference pattern (bottom line) between measured and calculated data are also shown

Table 1 Refined cell parameters and Rietveld refinement details for the studied $\mathrm{FeOHSO}_{4}$ sample at RT

\begin{tabular}{ll}
\hline Crystal system & Space group \\
\hline Space group & $C 2 / c$ \\
Unit cell dimensions: & \\
$a(\AA)$ & $7.388(1)$ \\
$b(\AA)$ & $7.1217(4)$ \\
$c(\AA)$ & $7.387(1)$ \\
$\beta\left({ }^{\circ}\right)$ & $120.556(2)$ \\
Cell volume $\left(\AA^{3}\right)$ & $334.70(2)$ \\
Density $\left(\mathrm{g} / \mathrm{cm}^{3}\right)$ & 3.352 \\
$2 \theta$ range for data collection $\left(^{\circ}\right)$ & 7.02 to 69.99 \\
$R_{\mathrm{wp}}(\%)$ & 2.26 \\
$R_{\mathrm{p}}(\%)$ & 2.08 \\
Reduced $\chi^{2}$ & 0.819 \\
$R\left(F^{2}\right)(\%)$ & 0.07 \\
\hline
\end{tabular}

displacement parameters of $\mathrm{O} 1, \mathrm{O} 2$, and $\mathrm{O} 3$ oxygens were constrained to be equal. The details of the Rietveld refinement are presented in Table 1, while the fractional coordinates and selected bond lengths are reported in Tables 2 and 3 , respectively. The resulting atomic arrangement of the unit cell is schematically presented in Fig. 2a. The structural details agree with the previous models (Ventruti et al. 2005), showing that the common building block to all members of the $\mathrm{FeOHSO}_{4}$ OD family is represented by a chain of trans corner-sharing $\mathrm{FeO}_{4}(\mathrm{OH})_{2}$ octahedra. $\mathrm{SO}_{4}$ tetrahedra alternate along the chain and interconnect adjacent chains by corner sharing all tetrahedral oxygen to form a 3D openframework. The position of the hydrogen atoms (Table 2) 
Table 2 Atomic coordinates and isotropic displacement parameters $\left(\AA^{2}\right)$ for the studied $\mathrm{FeOHSO}_{4}$ sample

\begin{tabular}{llllll}
\hline Atom & $\begin{array}{l}\text { Wyckoff } \\
\text { positions }\end{array}$ & $x$ & $y$ & $z$ & Uiso \\
\hline $\mathrm{Fe}$ & $4 \mathrm{c}$ & 0.25 & 0.25 & 0.0 & $0.024(2)$ \\
$\mathrm{S}$ & $4 \mathrm{e}$ & 0.0 & $0.1353(9)$ & 0.25 & $0.019(4)$ \\
$\mathrm{O} 1$ & $8 \mathrm{f}$ & $0.588(12)$ & $0.7575(16)$ & $0.154(12)$ & $0.010(3)$ \\
$\mathrm{O} 2$ & $4 \mathrm{e}$ & 0.0 & $0.6534(17)$ & 0.25 & $0.010(3)$ \\
$\mathrm{O} 3$ & $8 \mathrm{f}$ & $0.3413(20)$ & $0.4862(12)$ & $0.5817(22)$ & $0.010(3)$ \\
$\mathrm{H}^{*}$ & $4 \mathrm{e}$ & 0.0 & 0.52 & 0.25 & \\
\hline
\end{tabular}

*Calculated by DFT

Table 3 Selected interatomic distances $(\AA)$ for the studied $\mathrm{FeOHSO}_{4}$ sample

\begin{tabular}{llll}
\hline $\mathrm{Fe}-\mathrm{O} 1(\times 2)$ & $2.030(9)$ & $\mathrm{S}-\mathrm{O} 1(\times 2)$ & $1.465(13)$ \\
$\mathrm{Fe}-\mathrm{O} 2(\times 2)$ & $1.956(4)$ & $\mathrm{S}-\mathrm{O} 3(\times 2)$ & $1.479(11)$ \\
$\mathrm{Fe}-\mathrm{O} 3(\times 2)$ & $1.984(9)$ & $<\mathrm{S}-\mathrm{O}>$ & $1.472(12)$ \\
$<\mathrm{Fe}-\mathrm{O}>$ & $1.990(7)$ & & \\
\hline
\end{tabular}

(a)

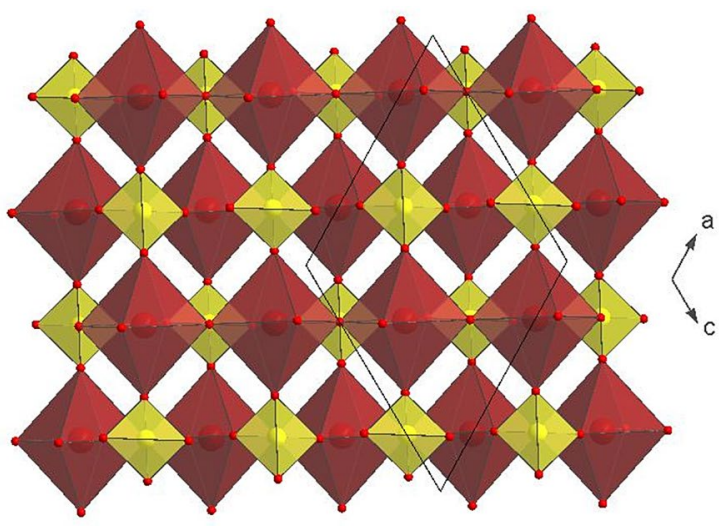

(b)

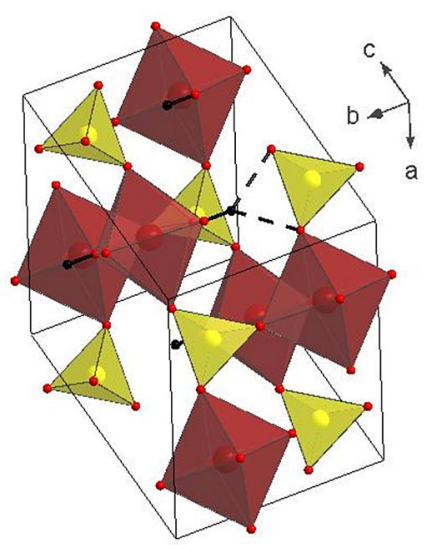

Fig. 2 a The linear chains present in the monoclinic $\mathrm{FeOHSO}_{4}$ b The monoclinic $\mathrm{FeOHSO}_{4}$ unit-cell showing the structural environment around the hydroxyl group at the $\mathrm{O} 2$ position and hydrogen-bonded to two $\mathrm{O} 1$ anions was obtained from electronic structure calculations using density functional theory (DFT). The experimentally determined unit-cell parameters and the heavy atom positions were used as an input geometry, and an approximate starting position for the hydrogen atom was employed. The resulting environment of the hydroxyl group at $\mathrm{O} 2$ position (Table 2) is shown in Fig. 2b. The $\mathrm{O}-\mathrm{H}$ vectors are perpendicular to the ferric chain and oriented towards the $\mathrm{O} 1 \mathrm{O} 1$ edge of the $\mathrm{SO}_{4}$ group. The two symmetric hydrogen-bond distances H..O1 of about $2.21 \AA$ suggest relatively weak interactions around the $\mathrm{OH}$ position.

The powdered sample used as starting material for XRPD experiments was then examined by TEM. We generally observed that the powder grains have lamellar habitus-with the longest dimension usually confined within some hundreds of nm. Furthermore, the EDS spectrum was found to be consistent with the expected composition (Fig. 3). SAED patterns taken on different grains are consistent with the $C 2 / c$ space group. It is worth to note that SAED patterns may indicate a $C 2 / m$ symmetry because of the presence of $h 0 l, l=2 n+1$ reflections, which should be systematically absent from the presence of the $c$-glide (Fig. 3). However, it is well known that in electron diffraction experiments, such reflections can be present due to dynamical scattering.

\section{Heating experiments on $\mathrm{FeOHSO}_{4}$ : TG and XRPD}

Two main endothermic peaks are observed in the DTA curve (Fig. 4a) at 536 and $682{ }^{\circ} \mathrm{C}$, respectively. FTIR spectra corresponding to the evolution of the gas involved during these two events were selected and analyzed. The first endothermic peak corresponds to the loss of the hydroxyl group. Indeed, the observed mass decrease in the thermal range from room temperature up to $530{ }^{\circ} \mathrm{C}$ is about $10 \mathrm{wt} \%$, very close to the expected theoretical value for the complete loss of one water molecule. Unfortunately, the very small concentration of evolved water vapor did not allow the detection of a significant FTIR signal. In the FTIR spectrum (Fig. 4b), associated with the second endothermic peak, the absorption bands of $\mathrm{SO}_{2}$ (at 1374, 1359, 1345, and $1166 \mathrm{~cm}^{-1}$ ) were identified. Therefore, the second mass loss of about $42 \%$ observed in the thermal range $570-750{ }^{\circ} \mathrm{C}$ is associated with the disruption of $\mathrm{SO}_{4}$ groups. Our results are in agreement with a combined thermogravimetric-mass spectroscopy analysis carried out by NETZSCH (AZO Materials 2009) that found a mass number of 18 and 64 plus 32 a.m.u. for the first and second mass loss, respectively.

$\mathrm{X}$-ray diffraction data (Fig. 5) show that the crystal structure of $\mathrm{FeOHSO}_{4}$ is not significantly affected by the thermal treatment up to $400{ }^{\circ} \mathrm{C}$, since the diffraction patterns are virtually identical in both peak multiplicity and intensities. 
Fig. 3 Representative brightfield (BF) image (a) and related EDS spectrum $(\mathbf{b})$ of the $\mathrm{FeOHSO}_{4}$ powder $(\mathrm{Cu}$ peaks come from the grid); c-e SAED patterns along some low-indexed orientations taken on different grains. All patterns can be indexed according to the $\mathrm{C} 2 / \mathrm{m}$ space group. Indexing in the $C 2 / c$ space group is possible, once it is assumed that $h 0 l$ reflections with $l=2 n+1$ that should be absent by symmetry are indeed present because of dynamical scattering (circles). Note that in (e), the [001] and [101] orientations cannot be distinguished (indexing according to the latter)
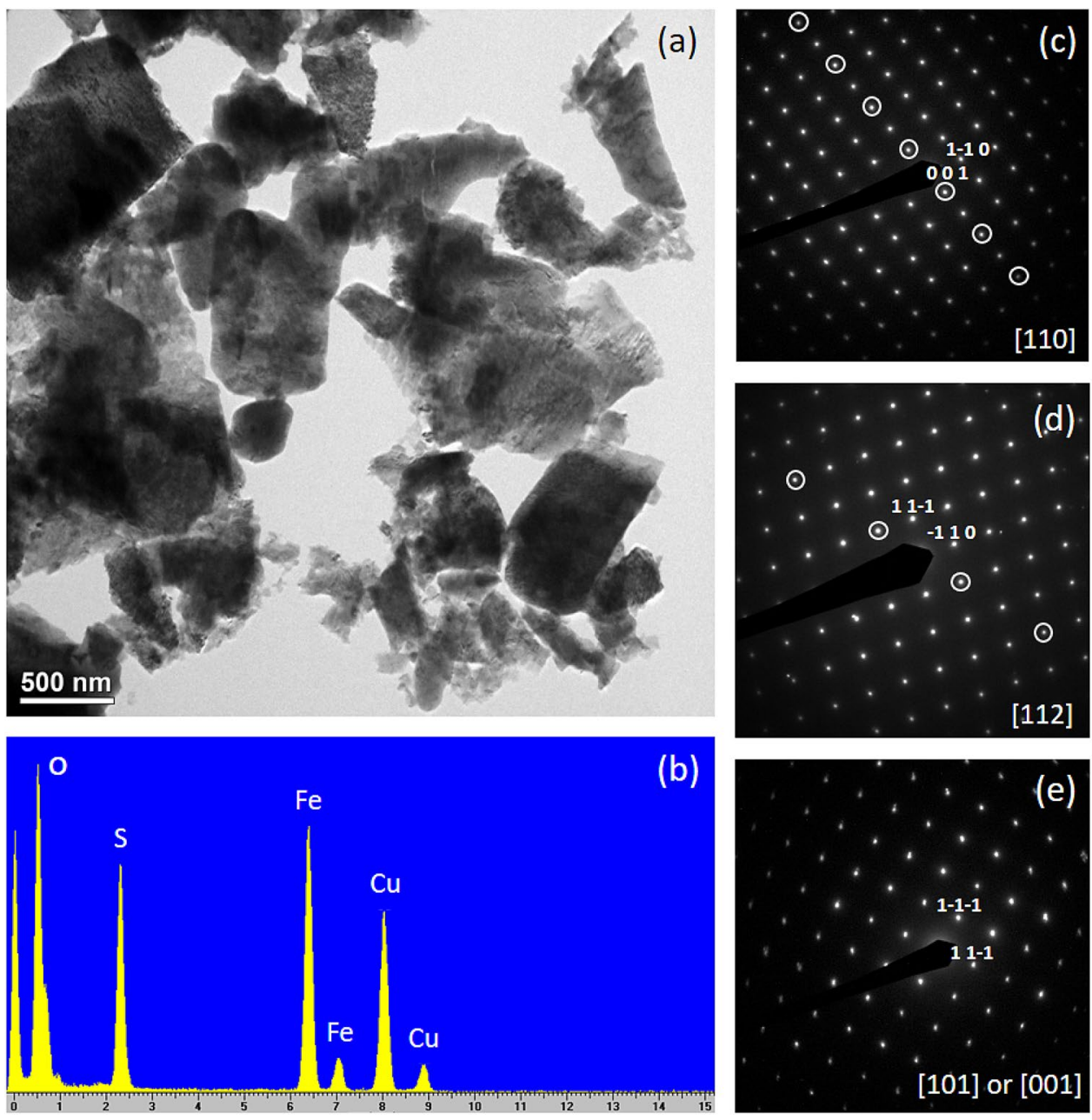

Inspection of the individual X-ray patterns shows that the $\mathrm{FeOHSO}_{4}$ phase is the only phase in the assemblage up to at least $400{ }^{\circ} \mathrm{C}$ (Fig. 5). The evolution of the lattice parameters and cell volume determined by GSAS as a function of $T$ is displayed in Fig. 6. In general, we observe that the axial expansion is strongly anisotropic. Up to $400{ }^{\circ} \mathrm{C}$, there is a decrease of the $a$ cell parameter, while the $b$ and $c$ cell parameters increase linearly. However, for all cell edges, the trend departs from linearity at $T>400{ }^{\circ} \mathrm{C}$. This is particularly evident for $b$ and the $\beta$ angle that show a sudden increase up to $500{ }^{\circ} \mathrm{C}$. The evolution of the cell volume (Fig. 6, Table S1), averaging the variation of the individual cell edges, shows a cumulative linear increase up to $400{ }^{\circ} \mathrm{C}$. A discontinuity in the positive variation of cell volume is observed at about $490{ }^{\circ} \mathrm{C}$ in correspondence of the phase transition discussed below. The thermal expansion coefficients for $\mathrm{FeOHSO}_{4}$ calculated by least-squares linear regression analysis between $\mathrm{RT}$ and $400{ }^{\circ} \mathrm{C}$ are $\alpha_{\mathrm{a}}=-2.51$ $910^{-6} \mathrm{~K}^{-1}, \alpha_{\mathrm{b}}=26.2910^{-6} \mathrm{~K}^{-1}$ and $\alpha_{\mathrm{c}}=10.610^{-6} \mathrm{~K}^{-1}$, $\alpha_{\mathrm{V}}=33.010^{-6} \mathrm{~K}^{-1}$.

Above $400{ }^{\circ} \mathrm{C}$, the basic iron hydroxyl sulfate undergoes a dehydroxylation process through two different mechanisms.
Initially, at about $450{ }^{\circ} \mathrm{C}$, the most intense diffraction peaks of $\alpha-\mathrm{Fe}_{2}\left(\mathrm{SO}_{4}\right)_{3}$ (Christidis and Rentzeperis 1976) appear in the pattern. No other phases were detected in the X-ray patterns up to $490^{\circ} \mathrm{C}$. Quantitative phase analysis via Rietveld refinement indicates that $\mathrm{FeOHSO}_{4}$ partially decomposes to $\alpha-\mathrm{Fe}_{2}\left(\mathrm{SO}_{4}\right)_{3}$ as represented by the following equation:

$3 \mathrm{FeOHSO}_{4} \rightarrow \mathrm{Fe}_{2}\left(\mathrm{SO}_{4}\right)_{3}+1 / 2 \mathrm{Fe}_{2} \mathrm{O}_{3(\mathrm{amorph})}+3 / 2 \mathrm{H}_{2} \mathrm{O}$.

At around $490{ }^{\circ} \mathrm{C}$, most of the ferric hydroxy sulfate undergoes an abrupt dehydroxylation process. This causes a new compound, the ferric oxysulfate $\mathrm{Fe}_{2} \mathrm{O}\left(\mathrm{SO}_{4}\right)_{2}$ (Sun et al. 2014), to form according to the reaction:

$2 \mathrm{FeOHSO}_{4} \rightarrow \mathrm{Fe}_{2} \mathrm{O}\left(\mathrm{SO}_{4}\right)_{2}+\mathrm{H}_{2} \mathrm{O}$.

The weight fractions of the phases occurring during the whole heating treatment refined employing the Rietveld method are shown graphically in Fig. 7 and indicate that most of $\mathrm{FeOHSO}_{4}$ decomposes to ferric oxysulfate $\left(\mathrm{Fe}_{2} \mathrm{O}\left(\mathrm{SO}_{4}\right)_{2}\right)$ in a very short temperature range, while only a small fraction of $\mathrm{FeOHSO}_{4}$ decomposes to the rhombohedral ferric sulfate $\left(\mathrm{Fe}_{2}\left(\mathrm{SO}_{4}\right)_{3}\right)$ in a slightly more extended range. 
Fig. 4 a TGA (black line), DTA (red line), and DTG (blue line) curves of $\mathrm{FeOHSO}_{4}$ collected under $\mathrm{N}_{2}$ atmosphere. b In situ IR spectrum of evolved gases at about $660{ }^{\circ} \mathrm{C}$

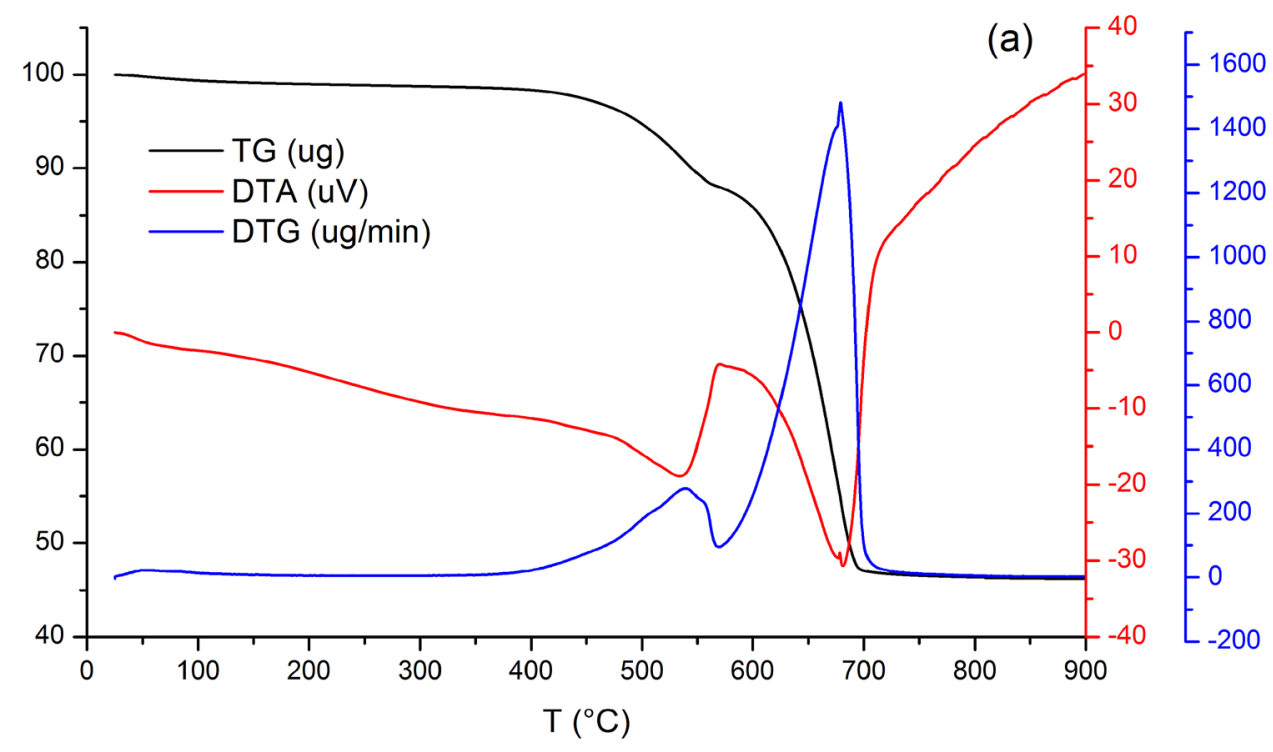

(b)

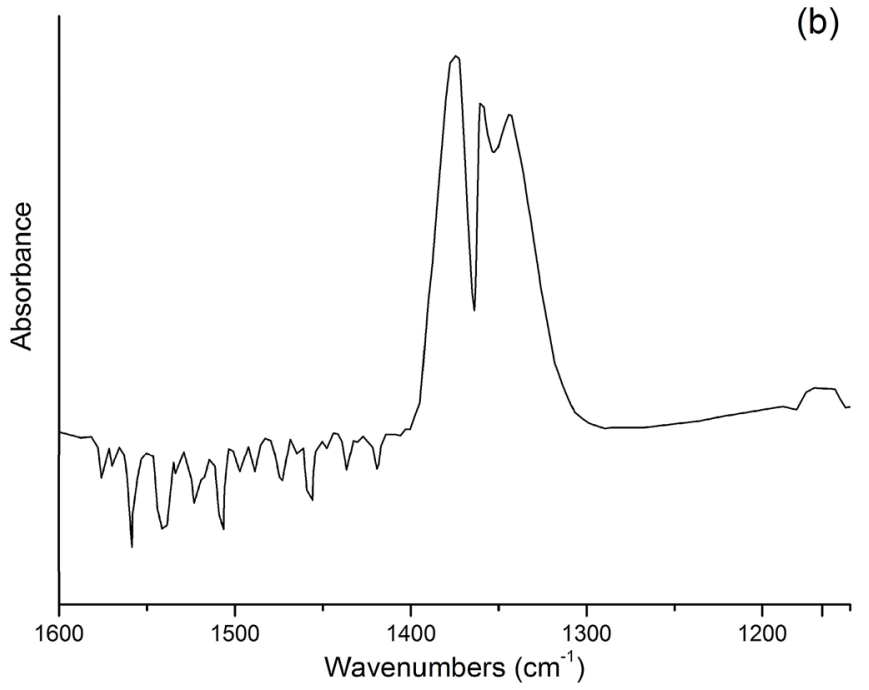

Indeed, the rhombohedral ferric sulfate increases gradually up to $580{ }^{\circ} \mathrm{C}$ that corresponds to the complete decomposition temperature of $\mathrm{FeOHSO}_{4}$, and then decreases until it disappears at $700{ }^{\circ} \mathrm{C}$ (Fig. 5b). At $580{ }^{\circ} \mathrm{C}$, the relative amount of $\alpha-\mathrm{Fe}_{2}\left(\mathrm{SO}_{4}\right)_{3}$ calculated from the Rietveld analysis of the powder X-ray pattern is around $18 \%$.

The ferric oxysulfate is stable in a very limited thermal range of $490-550^{\circ} \mathrm{C}$ (Fig. 7). We observed that the ferric oxysulfate fraction increases quickly up to $500{ }^{\circ} \mathrm{C}$, which corresponds with the abrupt dehydroxylation of $\mathrm{FeOHSO}_{4}$, and then suddenly drops off. Hence, suggesting this phase is stable in a narrow temperature range under the used experimental conditions. Both phase transformations of $\mathrm{FeOHSO}_{4}$ are associated with the loss of one water molecule, thus implying that the heating treatment induces the breakdown of the sulfate chain. In particular, the loss of the hydroxyl group shared by adjacent $\mathrm{Fe}^{3+} \mathrm{O}_{4}(\mathrm{OH})_{2}$ octahedra in the linear chain of the $\mathrm{FeOHSO}_{4}$ structure causes mainly the formation of dimers of edge-shared $\mathrm{Fe}^{3+} \mathrm{O}_{6}$ octahedra present in the $\mathrm{Fe}_{2} \mathrm{O}\left(\mathrm{SO}_{4}\right)_{2}$ structure, and, in lesser part, the building of a 3D framework of $\mathrm{Fe}^{3+} \mathrm{O}_{6}$ octahedra sharing all vertices with $\mathrm{SO}_{4}$ groups to form rhombohedral $\mathrm{Fe}_{2}\left(\mathrm{SO}_{4}\right)_{3}$.

For $T>500{ }^{\circ} \mathrm{C}$, the $\alpha-\mathrm{Fe}_{2} \mathrm{O}_{3}$ iron oxide (hematite) appears in the assemblage and increases quickly to become the predominant phase for $T>600{ }^{\circ} \mathrm{C}$, and the only component for $T>700{ }^{\circ} \mathrm{C}$. The total mass loss observed in the thermogravimetric plot (Fig. 4) is in agreement with the expected theoretical value $52.7 \mathrm{wt} \%$ associated with the water and sulfur dioxide emission according to the overall reaction process:

$2 \mathrm{FeOHSO}_{4} \rightarrow \mathrm{Fe}_{2} \mathrm{O}_{3}+2 \mathrm{SO}_{2}+\mathrm{H}_{2} \mathrm{O}+\mathrm{O}_{2}$. 


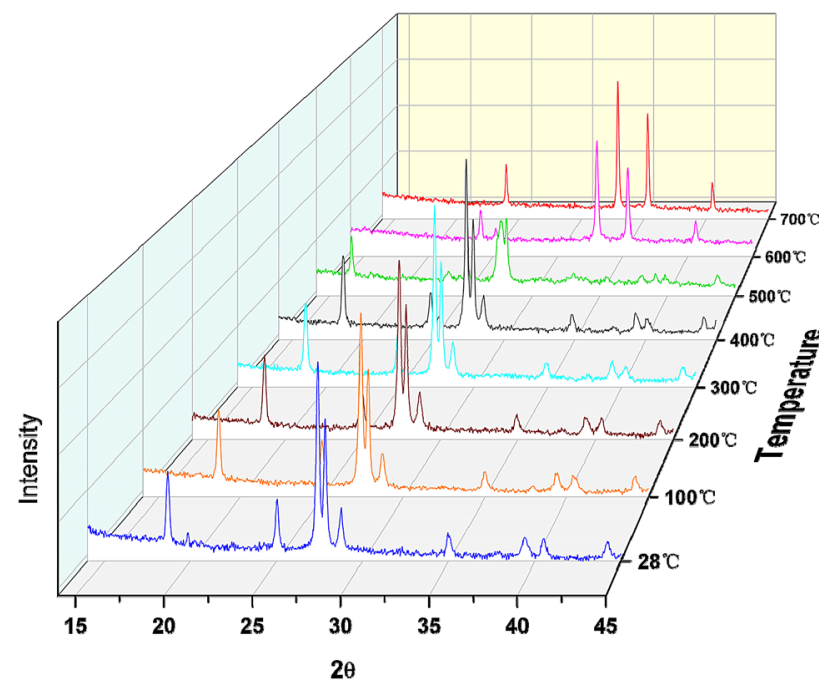

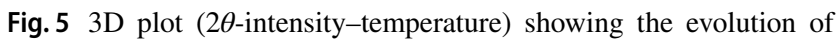
the XRPD patterns in the RT- $700^{\circ} \mathrm{C} \mathrm{T}$ range, in the $15-45^{\circ} 2 \theta$ region for the studied $\mathrm{FeOHSO}_{4}$ sample

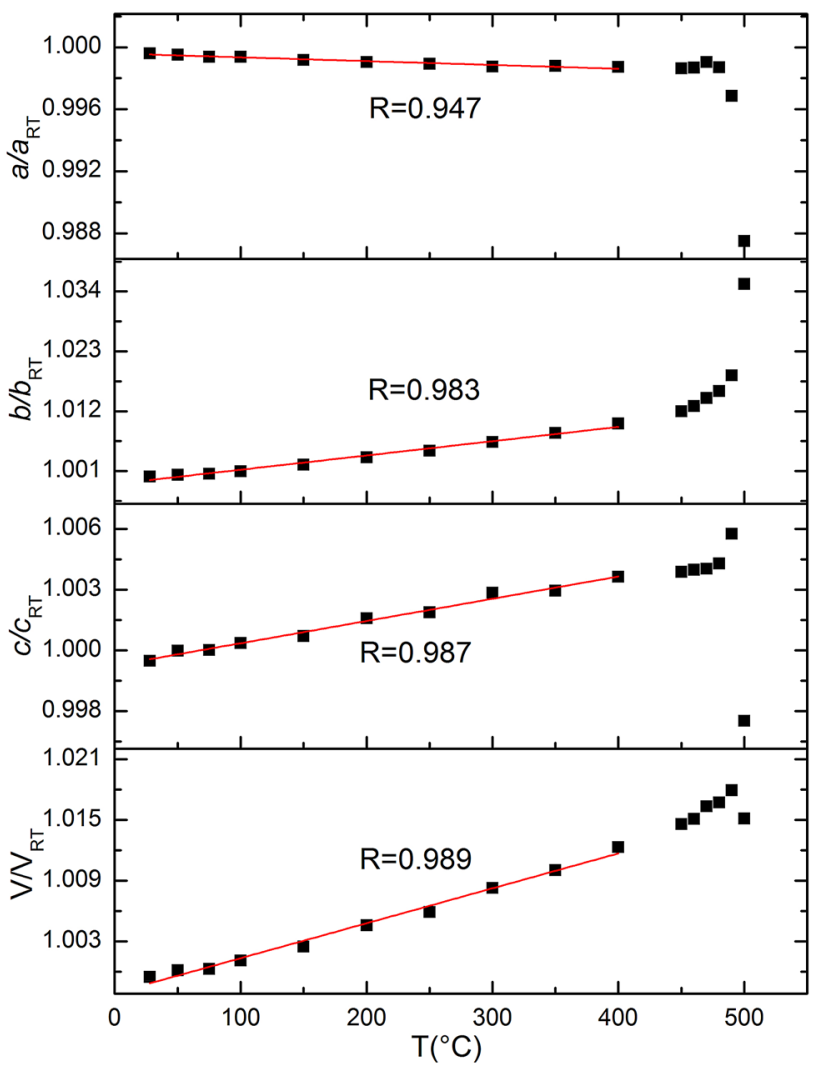

Fig. 6 Evolution of cell parameters and volume, normalized at RT values, along with the thermal expansion of $\mathrm{FeOHSO}_{4}$. Linear regressions (red lines) through the $\mathrm{RT}-400{ }^{\circ} \mathrm{C}$ range are also reported

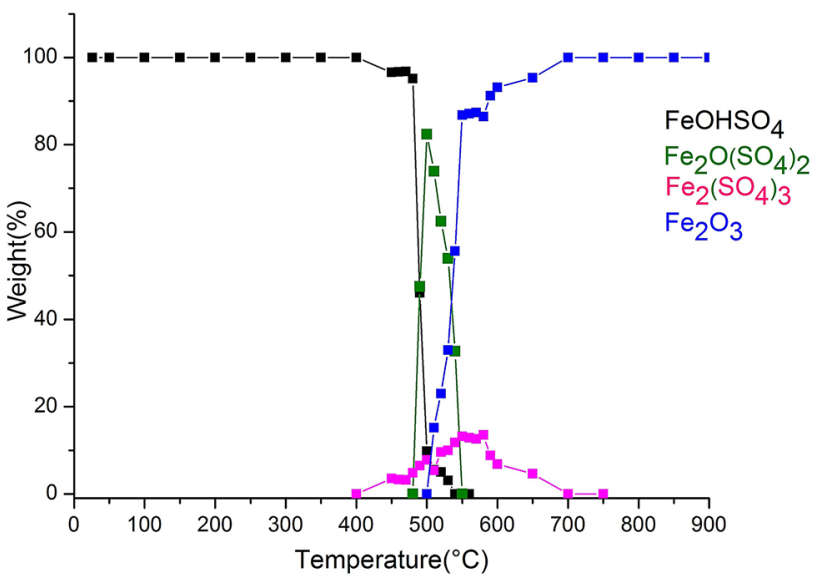

Fig. 7 Evolution of the phase amounts refined from the Rietveld method based on the powder X-ray diffraction patterns in the RT-900 ${ }^{\circ} \mathrm{C}$ range

\section{The RT vibrational (FTIR and Raman) spectra of $\mathrm{FeOHSO}_{4}$}

The RT FTIR and Raman spectra collected for the studied $\mathrm{FeOHSO}_{4}$ sample are given in Fig. 8. To the best of our knowledge, no complete Raman data exist in the literature for this compound except an RT Raman spectrum in the limited wavenumber range of $\mathrm{SO}_{4}$ internal modes (Connor and Wang 2014); FTIR spectra, on the other side, have been published in some previous papers (Powers et al. 1975; Majzlan et al. 2011; Gomez et al. 2013). In the principal OHstretching region (4000-3000 $\mathrm{cm}^{-1}$ ), a single and very sharp peak (Fig. 8a) is present in the Raman pattern, at $3447 \mathrm{~cm}^{-1}$, while for the powder FTIR spectrum, this band occurs at $3454 \mathrm{~cm}^{-1}$. The FTIR band is, however, broader with respect to the Raman peak, and strongly asymmetric, possibly due to an overlapping component on the lower wavenumber side, at around $3320 \mathrm{~cm}^{-1}$ (Fig. 8b). In the $4000-5000 \mathrm{~cm}^{-1}$ NIR region, a unique band due to the combination of the stretching and libration modes $\left({ }^{\mathrm{OH}_{2}}{ }_{3}+{ }^{\mathrm{OH}} \delta\right)$ is observed at $4470 \mathrm{~cm}^{-1}$ (Fig. 9). No bands are observed at wavenumbers $>5000 \mathrm{~cm}^{-1}$, ruling out any presence of $\mathrm{H}_{2} \mathrm{O}$ molecules in the structure (Della Ventura et al. 2009, 2013; Ventruti et al. 2015, 2018). Considering a single ${ }^{\mathrm{OH}_{\nu_{3}}}$ at $3454 \mathrm{~cm}^{-1}$, an $\mathrm{OH}$ libration around $1020 \mathrm{~cm}^{-1}$ is expected based on the spectrum of Fig. 9.

The spectra in the low-wavenumber $\left(<1200 \mathrm{~cm}^{-1}\right)$ range show the typical modes resulting from vibrations of the $\mathrm{SO}_{4}$ group, the $\mathrm{Fe}-\mathrm{O}$ octahedra, and the libration of the $\mathrm{OH}$ groups $\left(\delta_{\mathrm{OH}}\right)$ (e.g., Powers et al. 1975). For sulfate minerals, if the ideal $T_{\mathrm{d}}$ symmetry of the $\mathrm{SO}_{4}$ group is lowered due to the interaction with the surrounding atoms, the degeneracy of the $\nu_{3}$ mode is lifted, and the vibrations inactive in tetrahedral symmetry become IR active (e.g., Majzlan et al. 2011). As 
Fig. 8 RT Raman spectrum a compared with the powder FTIR spectrum $\mathbf{b}$ for the studied $\mathrm{FeOHSO}_{4}$ sample, in the whole MIR range

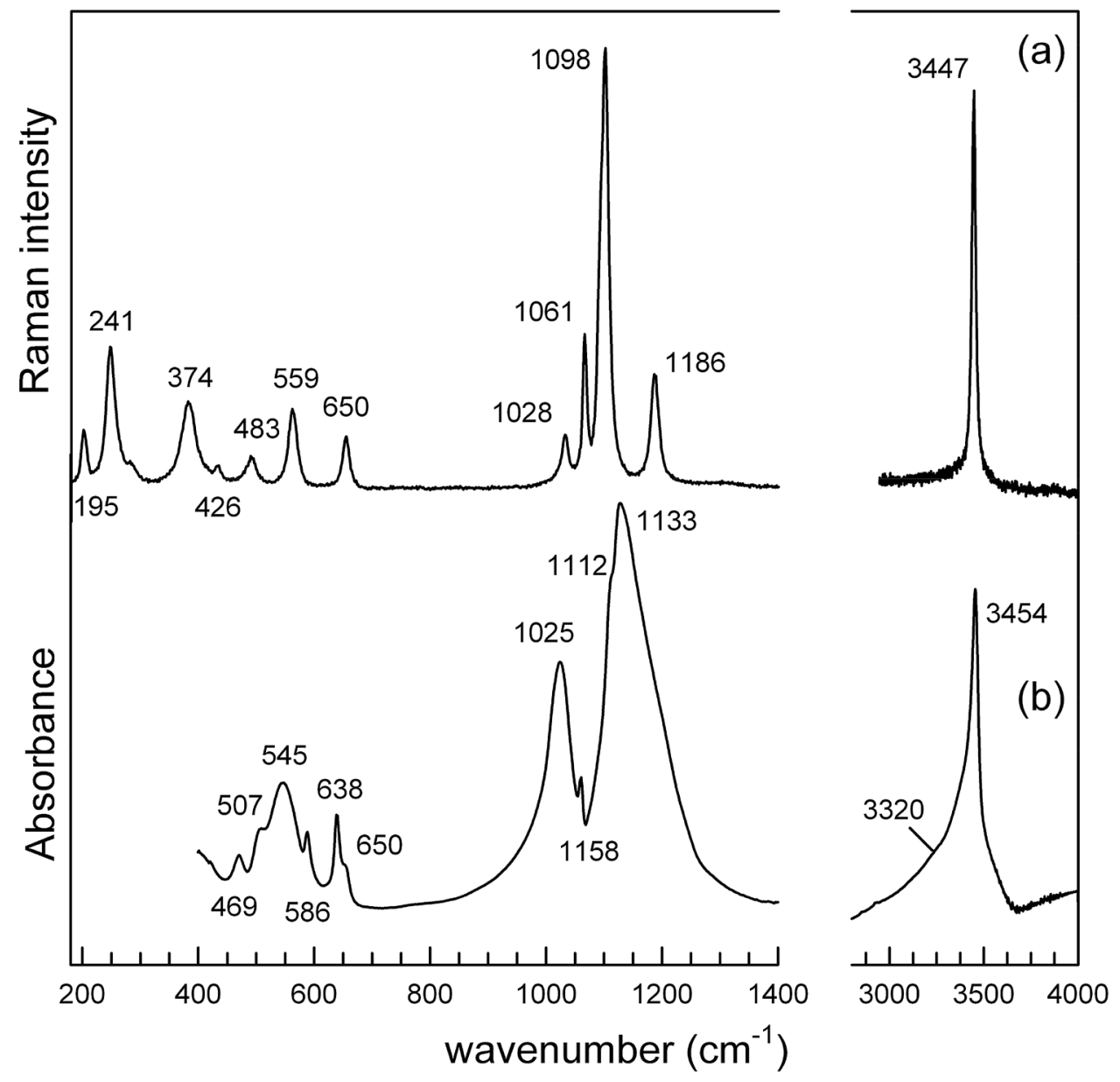

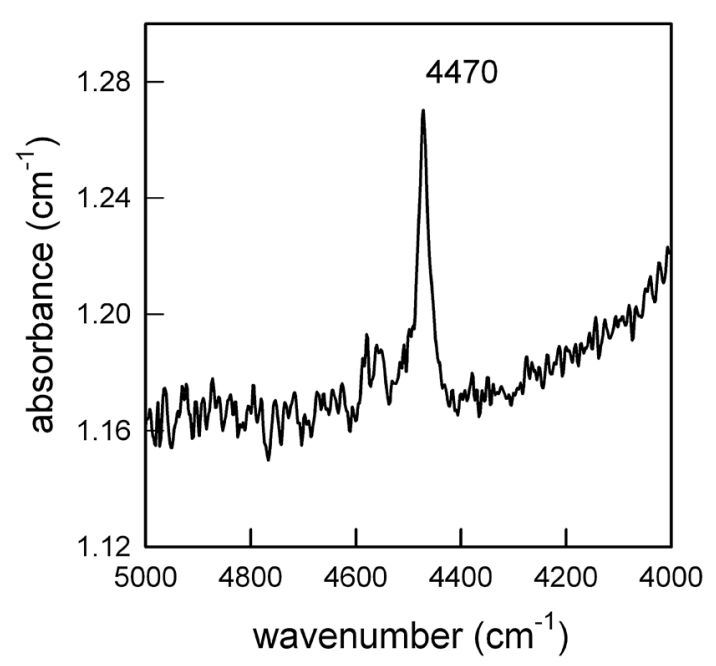

Fig. 9 RT NIR (near-infrared) spectrum for the studied $\mathrm{FeOHSO}_{4}$ sample

a consequence, each crystallographically distinct $\mathrm{SO}_{4}$ tetrahedron contributes up to four bands (three $v_{3}+$ one $v_{1}$ ) to the spectra. The IR spectrum of $\mathrm{FeOHSO}_{4}$, in particular, has been examined by Powers et al. (1975) who assigned four sulfate bands to these modes in the $1172-1058 \mathrm{~cm}^{-1}$ range, plus the $\delta_{\mathrm{OH}}$ at $1020 \mathrm{~cm}^{-1}$. Two peaks at 650 and $638 \mathrm{~cm}^{-1}$, respectively, were assigned to the $\nu_{4}$ modes, while several bands in the $400-600 \mathrm{~cm}^{-1}$ range were tentatively assigned to $\mathrm{Fe}-\mathrm{O}$ modes. The spectrum collected here is very similar in multiplicity and band position to that reported by Powers et al. (1975), except for a few differences in band intensity of the $\nu_{3}-\mathrm{SO}_{4}$ higher wavenumber region.

Assignment of the peaks observed in the Raman spectrum can be based on comparison with the IR pattern and with data from the literature on similar compounds (Sasaki et al. 1998; Frost et al. 2006). Accordingly, the peaks at 1186, 1098, and $1061 \mathrm{~cm}^{-1}$ in the Raman pattern are assigned to the $\nu_{3}+\nu_{1} \mathrm{SO}_{4}$ modes. Meanwhile, that at $1028 \mathrm{~cm}^{-1}$ is assigned to the $\delta_{\mathrm{OH}}$ mode (Sasaki et al. 1998), while the $v_{4} \mathrm{SO}_{4}$ mode is found at $650 \mathrm{~cm}^{-1}$ and those in the $600-200$ range to the $\nu_{2} \mathrm{SO}_{4}$ and $\mathrm{Fe}-\mathrm{O}$ octahedral modes. 


\section{Heating experiments on $\mathrm{FeOHSO}_{4}$ : vibrational (Raman and FTIR) spectroscopies}

The Raman spectra collected in situ both in the lattice mode region $\left(<1200 \mathrm{~cm}^{-1}\right)$ and the $3000-4000 \mathrm{~cm}^{-1} \mathrm{O}-\mathrm{H}$ stretching region are given in Fig. 10. The Raman pattern in the fingerprint region remains almost unaffected at least up to $300^{\circ} \mathrm{C}$. However, the appearance of an intense fluorescence background, due to energy emission in the IR spectral region from the heating stage, strongly interferes, preventing to extend the limit for the basic ferric hydroxyl sulfate stability beyond $400{ }^{\circ} \mathrm{C}$, as identified by TG and XRPD data. However, the $\mathrm{OH}$-stretching band is less affected by thermal treatment, the only appreciable effect being a slight broadening and a small reduction of its intensity. At higher temperatures $\left(>500{ }^{\circ} \mathrm{C}\right)$, the

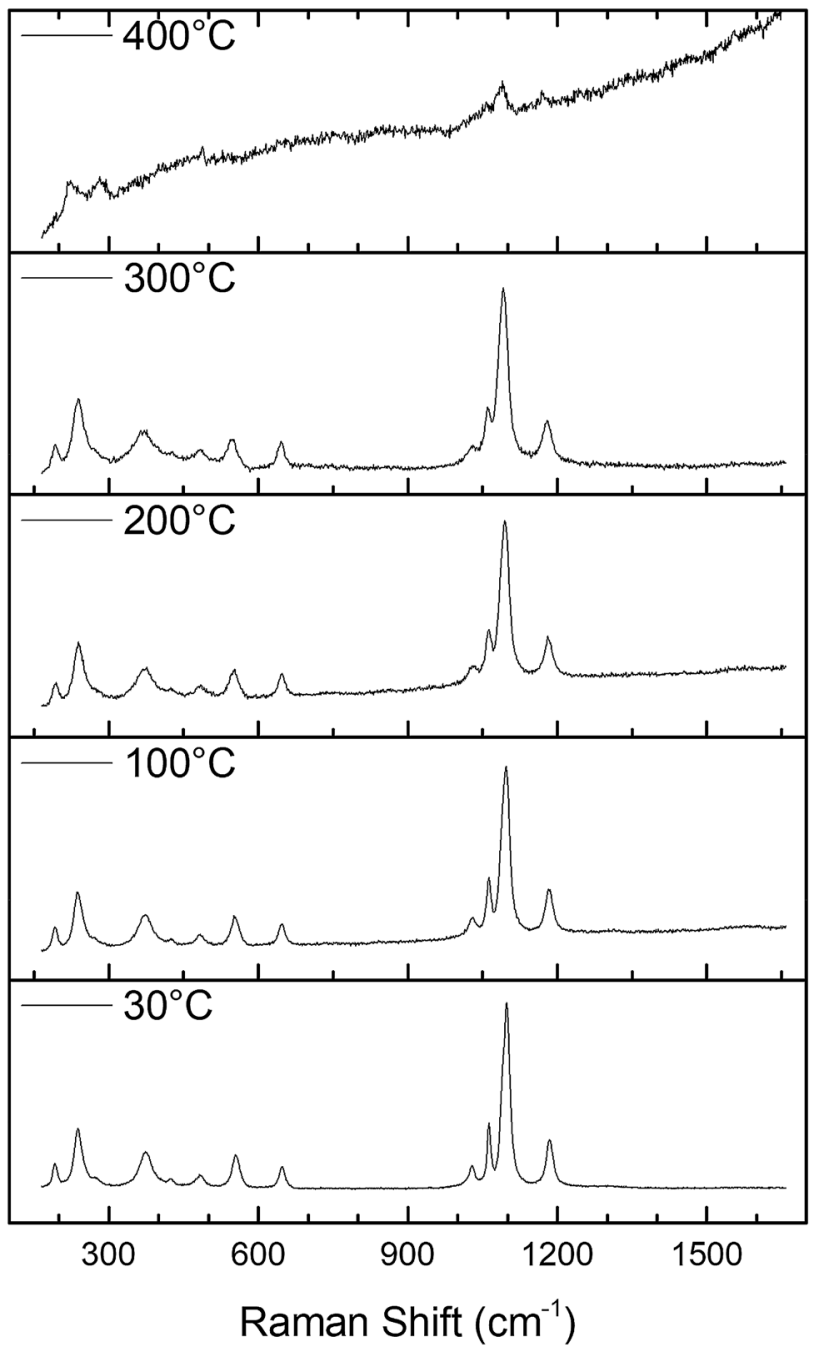

collected spectra are dominated by fluorescence. To overcome this bottleneck, Raman spectra have been collected at RT after annealing the sample. Figure 11 displays the spectra labelled in terms of the target temperature of each annealing step. It is worth noting that the Raman spectrum collected at RT after the sample was annealed at $400{ }^{\circ} \mathrm{C}$ completely recovered its shape, while for $\mathrm{T}$ exceeding $500{ }^{\circ} \mathrm{C}$, it started to change. In particular, a broad band appears in the $400-500 \mathrm{~cm}^{-1}$ range, while still showing slightly broadened sulfate modes, a trend that is confirmed at $580{ }^{\circ} \mathrm{C}$ where the spectral signature in the framework mode region is completely wrecked and a very broad $\mathrm{OH}$ contribution is still visible. Interestingly, this is the $T$ range where XRPD data show the onset of metastable sulfate phases and, because the Raman spectra are collected at RT after the sample was annealed, we can infer that this represents the starting point of irreversibility for

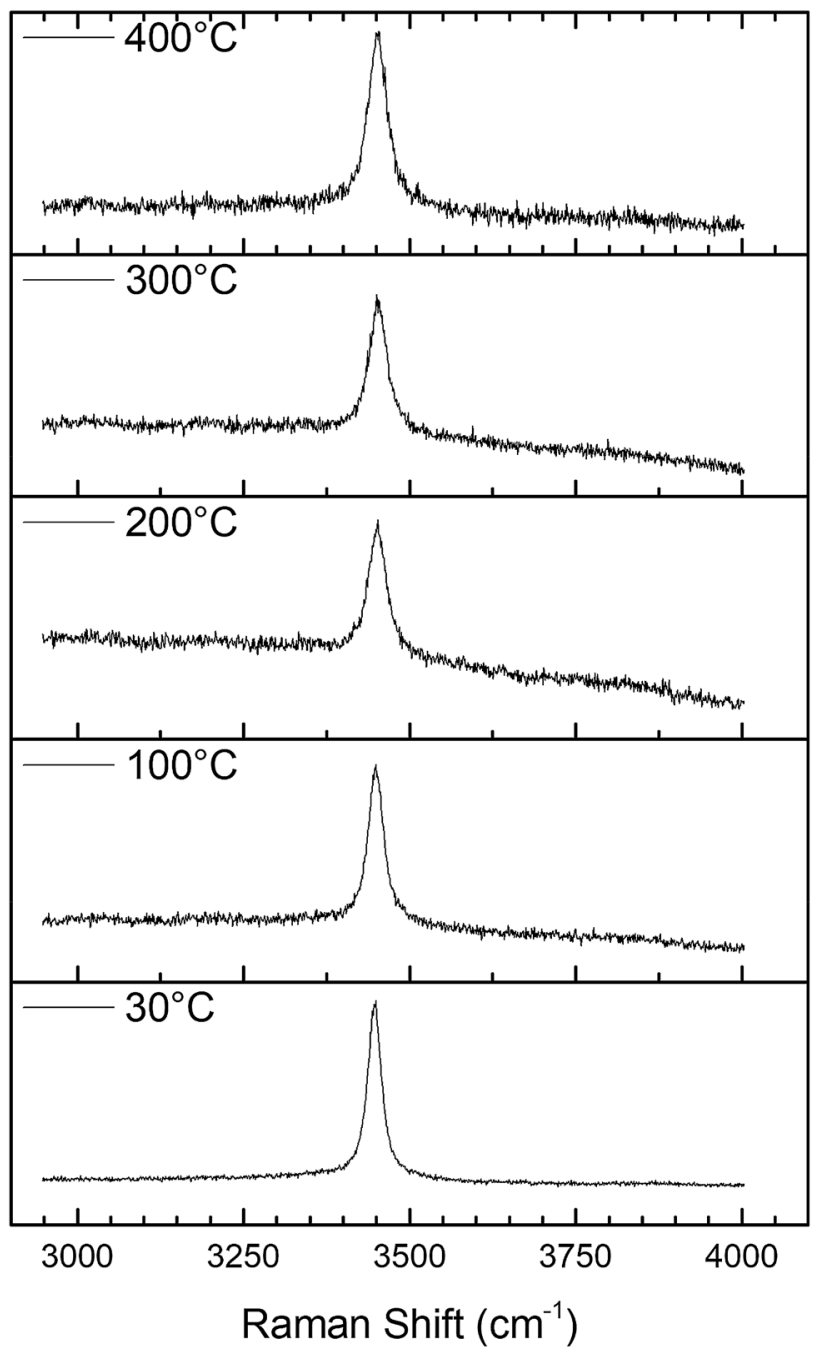

Fig. 10 Raman spectra for the studied $\mathrm{FeOHSO}_{4}$ collected in situ for increasing temperature $\left({ }^{\circ} \mathrm{C}\right.$, indicated on each pattern): a low-frequency mode region and $\mathbf{b} \mathrm{OH}$-stretching region 

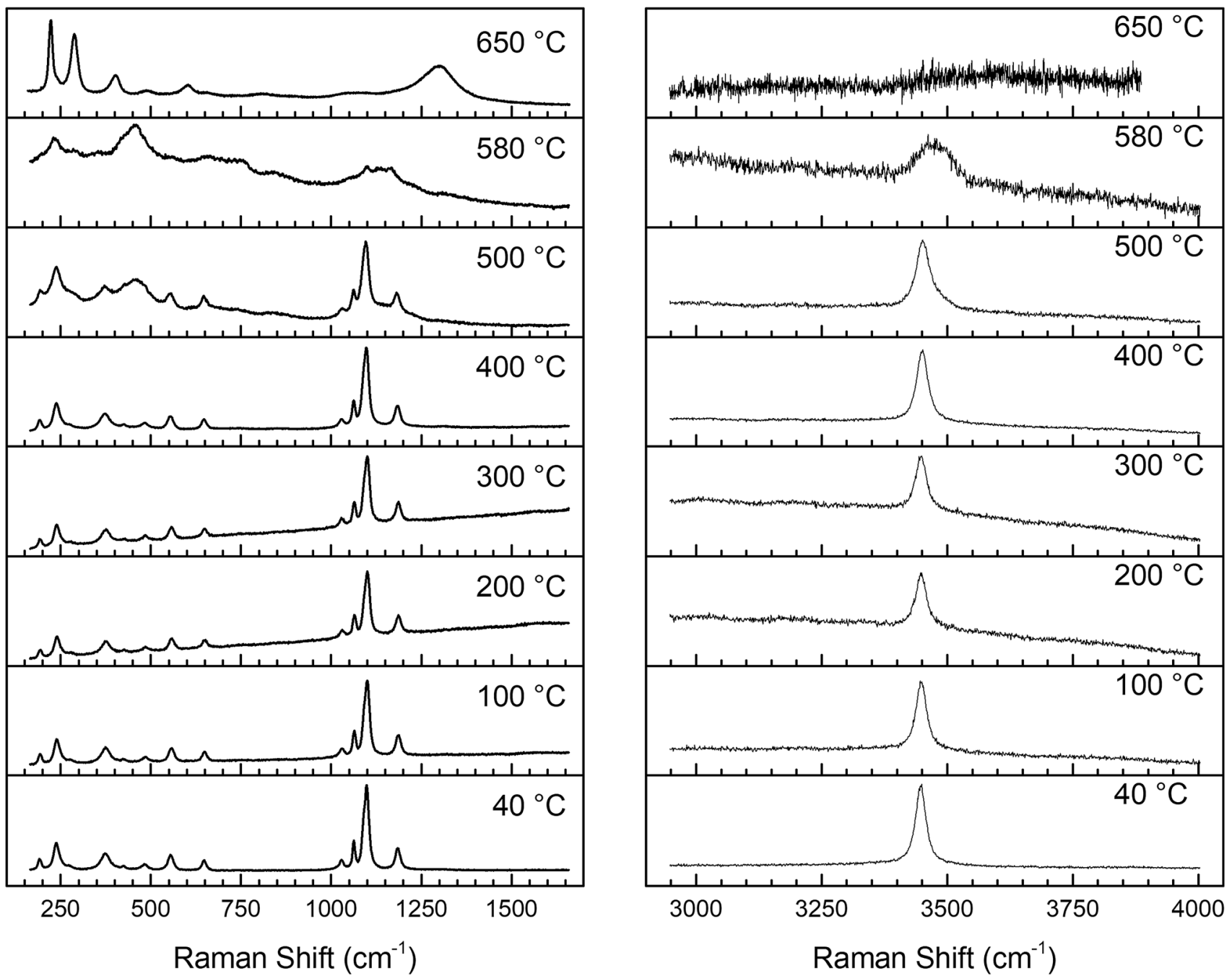

Fig. 11 Raman spectra for the studied $\mathrm{FeOHSO}_{4}$ collected ex situ for increasing temperature $\left({ }^{\circ} \mathrm{C}\right.$, indicated on each pattern): a low-frequency mode region and $\mathbf{b} \mathrm{OH}$-stretching region

the reaction. The Raman spectrum collected after annealing the sample at $650{ }^{\circ} \mathrm{C}$ shows, in agreement with XRPD data, the unique presence of hematite $\mathrm{Fe}_{2} \mathrm{O}_{3}$, that is the new stable phase after completion of the dehydration process.

The loss of $\mathrm{H}$ during the thermal treatment of $\mathrm{FeOHSO}_{4}$ was monitored by in situ FTIR micro-spectroscopy. Based on the previous experience on dehydration experiments on different substances (e.g., Della Ventura et al. 2018), we collected the data on pure powder deposited on a sample holder. This choice was preferred instead of using the classical technique of embedding the sample within an IR transparent medium (i.e., $\mathrm{KBr}$ ) to avoid possible ambiguities due to incomplete loss of $\mathrm{H}$ across the compressed matrix. Because of the saturation of the detector in the principal $\mathrm{OH}$-stretching region, even for small amounts of powder under the IR beam, we monitored the intensity of the NIR band (Fig. 9). The evolution of the peak intensity as a function of temperature is given in Fig. 12a which shows a sudden loss of the $\mathrm{O}-\mathrm{H}$ signal for $T>500{ }^{\circ} \mathrm{C}$ that is completed in a short $T$ range (ca $50{ }^{\circ} \mathrm{C}$ ). Interestingly, the data show a significant intensity increase close to the verge of dehydration. Such a feature cannot be due to an increase of the $\mathrm{OH}$ content during the thermal treatment; it has been observed in other studies on the thermal behaviour of Fe-rich hydroxy-silicates (e.g., Della Ventura et al. 2018) and has been explained as due to enlarged amplitudes of hydrogen atomic displacement for increasing $T$. Figure $12 \mathrm{~b}$ shows that a very slight intensity increase is possibly also visible in the Raman spectra. Figure 12 thus suggests that such a feature is common to different compounds where the $\mathrm{H}$ loss is connected to a structural rearrangement involving the $\mathrm{Fe}$ electronic properties, as observed for some Fe silicates (Della Ventura et al. 2018). 
Fig. 12 Evolution of normalized intensity (area) as a function of T of a the NIR peak at $4472 \mathrm{~cm}^{-1}$ and $\mathbf{b}$ the $\mathrm{OH}-$ stretching band at $3447 \mathrm{~cm}^{-1}$ in the Raman spectra
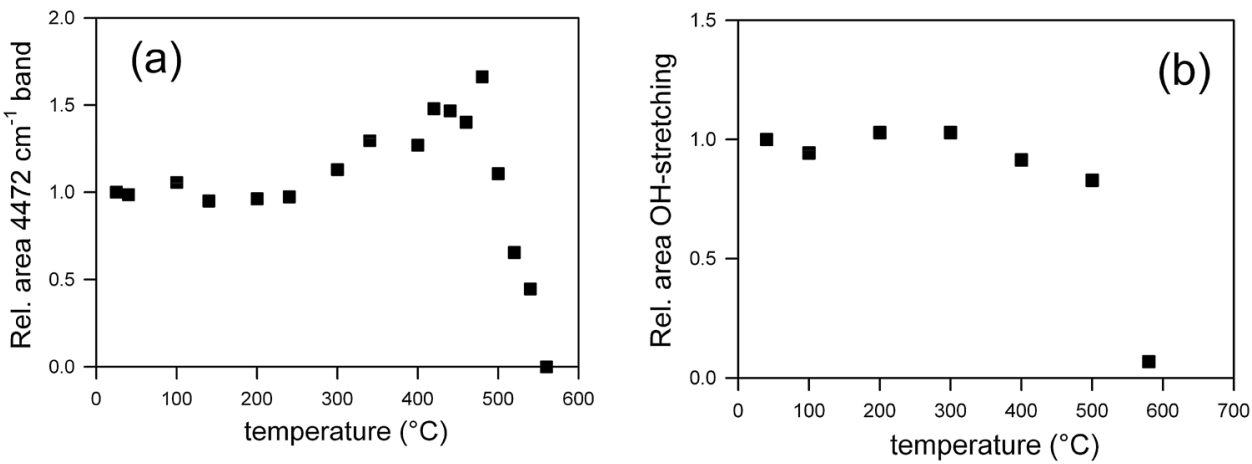

\section{Conclusions}

In this paper, we addressed the crystal chemistry of basic ferric sulfate, a synthetic compound with interesting material properties. Our data confirmed that the monoclinic polytype of this compound is better described in the $C 2 / c$ space group. We examined the thermal behaviour and the phase transformation for increasing $T$. The combination of TG and XRPD results showed that basic ferric sulfate is stable up to $450{ }^{\circ} \mathrm{C}$. Meanwhile, in the $450<T<550{ }^{\circ} \mathrm{C}$ range, this compound is replaced by a mixture of $\mathrm{Fe}_{2} \mathrm{O}\left(\mathrm{SO}_{4}\right)_{2}$ plus rhombohedral $\mathrm{Fe}_{2}\left(\mathrm{SO}_{4}\right)_{3}$. The stability ranges of these two $\mathrm{Fe}$ sulfates are restricted to a very narrow $T$ range $\left(\sim 100{ }^{\circ} \mathrm{C}\right)$, and for $T>700^{\circ} \mathrm{C}$, only hematite is present in the sample.

Acknowledgements We thank the two anonymous reviewers whose comments/suggestions helped to improve the clarity of this manuscript. The XRPD laboratory at the Dipartimento di Scienze della Terra and Geoambientali, University of Bari "Aldo Moro", was funded by Potenziamento Strutturale PONa3_00369 "Laboratorio per lo Sviluppo Integrato delle Scienze e delle TEcnologie dei Materiali Avanzati e per dispositivi innovativi (SISTEMA)". Part of this work was supported by a Grant to Department of Science, Roma Tre University (MIURItaly Dipartimenti di Eccellenza, ARTICOLO 1, COMMI 314-337 LEGGE 232/2016).

Funding Open access funding provided by Università degli Studi di Bari Aldo Moro within the CRUI-CARE Agreement.

Open Access This article is licensed under a Creative Commons Attribution 4.0 International License, which permits use, sharing, adaptation, distribution and reproduction in any medium or format, as long as you give appropriate credit to the original author(s) and the source, provide a link to the Creative Commons licence, and indicate if changes were made. The images or other third party material in this article are included in the article's Creative Commons licence, unless indicated otherwise in a credit line to the material. If material is not included in the article's Creative Commons licence and your intended use is not permitted by statutory regulation or exceeds the permitted use, you will need to obtain permission directly from the copyright holder. To view a copy of this licence, visit http://creativecommons.org/licenses/by/4.0/.

\section{References}

Adams MD (2016) Gold ore processing: project development and operations, 2nd edn. Elsevier, Amsterdam

AZO Materials (2009) Simultaneous thermal analysis of iron hydroxy sulfate. AZoM.com Azo network site. https://www.azom.com/ article.aspx?ArticleID=4981. Accessed 26 April 2020

Bruce R, Mayhew L, Demopoulos G, Heidel A (2012) Arsenic stability and characterization of CESL process residues. Canadian Institute of Mining, Metallugy and Petroleum, Ontario

Cliff G, Lorimer GW (1975) The quantitative analysis of thin specimens. J Microsc 103:203-207

Cheng TC, Demopoulos GP (2004) Hydrolysis of ferric sulfate in the presence of zinc sulfate at $200{ }^{\circ} \mathrm{C}$ : precipitation kinetics and product characterization. Ind Eng Chem Res 43:6299-6308

Connor K, Wang A (2014) Laser Raman spectroscopy study of the dehydration and rehydration processes of ferrous sulfates. 11th International GeoRaman Conference (June 15-19, 2014, St. Louis, MO, USA) Abstract \#5008

Christidis PC, Rentzeperis PJ (1976) The crystal structure of rhombohedral $\mathrm{Fe}_{2}\left(\mathrm{SO}_{4}\right)_{3}$. Z Kristallogr 144:341-352

Della Ventura G, Gatta D, Redhammer G, Bellatreccia F, Loose A, Parodi GC (2009) Single-crystal polarized FTIR spectroscopy and neutron diffraction refinement of cancrinite. Phys Chem Miner 36:193-206

Della Ventura G, Ventruti G, Bellatreccia F, Scordari F, Cestelli Guidi M (2013) FTIR transmission spectroscopy of sideronatrite, a sodium iron hydrous sulfate. Mineral Mag 77:499-504

Della Ventura G, Milahova B, Susta U, Cestelli Guidi M, Marcelli A, Schlüter J, Oberti R (2018) The dynamics of Fe oxydation in riebeckite: a model for amphiboles. Am Miner 103:1103-1111

Dutrizac JE, Jambor JL (2007) Characterization of the iron arsenatesulphate compounds precipitated at elevated temperatures. Hydrometallurgy 86:147-163

Fleming CA (2009) Basic iron sulphate-a potential killer for pressure oxidation processing of refractory gold concentrates if not handled appropriately. SGS Minerals Services Technical Paper 2009-06

Fleming CA (2010) Basic iron sulfate- a potential killer in the processing of refractory gold concentrates by pressure oxidation. Miner Metall Process 27(2):81-88. https://doi.org/10.1007/bf03402383

Frost RL, Willis RA, Weier ML, Martens W, Mills S (2006) A Raman spectroscopic study of selected natural jarosites. Spectrochim Acta A 63:1-8

Gemmi M, Klein H, Rageau A, Strobel P, Le Cras F (2010) Structure solution of the new titanate $\mathrm{Li}_{4} \mathrm{Ti}_{8} \mathrm{Ni}_{3} \mathrm{O}_{21}$ using precession electron diffraction. Acta Cryst B66:60-68. https://doi.org/10.1107/ S010876810904631X

Gomez M, Becze L, Cutler J, Demopoulos G (2011) Hydrothermal reaction chemistry and characterization of ferric arsenate phases 
precipitated from $\mathrm{Fe}_{2}\left(\mathrm{SO}_{4}\right)_{3}-\mathrm{As}_{2} \mathrm{O}_{5}-\mathrm{H}_{2} \mathrm{SO}_{4}$ solutions. Hydrometallurgy 107:74-90

Gomez MA, Ventruti G, Celikin M, Assaaoudi H, Putz H, Becze L, Leea KE, Demopoulos GP (2013) The nature of synthetic basic ferric arsenate sulfate $\left(\mathrm{Fe}\left(\mathrm{AsO}_{4}\right)_{1-\mathrm{x}}\left(\mathrm{SO}_{4}\right)_{\mathrm{x}}(\mathrm{OH})_{\mathrm{x}}\right)$ and basic ferric sulfate $\left(\mathrm{FeOHSO}_{4}\right)$ : their crystallographic, molecular and electronic structure with applications in the environment and energy. RSC Adv 37:16840-16849

Johansson $\mathrm{G}$ (1962) On the crystal structure of $\mathrm{FeOHSO}_{4}$ and $\mathrm{InOHSO}_{4}$. Acta Chem Scand 16:1234-1244

Larson AC, Von Dreele RB (2000) General Structure Analysis System (GSAS). Los Alamos National Laboratory Report LAUR 86-748

Li and Sun (2017) Application of X-ray diffraction and electron crystallography for solving complex structure problems. Acc Chem Res 50(11):2737-2745

Mahapatra S, Prasad TP, Rao KK, Nayak R (1990) Thermal decomposition of hydrolysis products of $\mathrm{Fe}(\mathrm{OH}) \mathrm{SO}_{4}$. Thermochim Acta 161:279-285

Majzlan J, Alpers CN, Bender Koch C, McCleskey RB, Myneni SCB, Neil JM (2011) Vibrational, X-ray absorption, and Mössbauer spectra of sulfate minerals from the weathered massive sulfide deposit at Iron Mountain, California. Chem Geol 284:296-305

Paktunc D, Majzlan J, Palatinus L, Dutrizac J, Klementova M, Poirier G (2013) Characterization of ferric arsenate-sulfate compounds: implications for arsenic control in refractory gold processing residues. Am Miner 98:554-565

Palatinus L, Brázda P, Boullay P, Perez O, Klementová M, Petit S, Eigner V, Zaarour M, Mintova S (2017) Hydrogen positions in single nanocrystals revealed by electron diffraction. Science 355:166-169

Pelovski Y, Petkova V, Nikolov S (1996) Study of the mechanism of the thermochemical decomposition of ferrous sulphate monohydrate. Thermochim Acta 274:273-280

Powers DA, Rossman GR, Schugar HJ, Gray HB (1975) Magnetic behavior and infrared spectra of jarosite, basic iron sulfate and their chromate analogs. J Solid State Chem 13:1-13

Putz H, Schoen JC, Jansen M (1999) Combined method for ab initio structure solution from powder diffraction data. Appl Crystallogr 32:864-870

Reddy MA, Pralong V, Caignaert V, Varadaraju UV, Raveau B (2009) Monoclinic iron hydroxy sulphate: a new route to electrode materials. J Electrochem Commun 11:1807

Sasaki K, Tanaike O, Konno H (1998) Distinction of jarosite-group compounds by Raman spectroscopy. Can Miner 36:1225-1235

Saunders VR, Dovesi R, Roetti C, Orlando R, Zicovich-Wilson CM, Harrison NM, Doll K, Civalleri B, Bush LJ, D’Arco Ph, Llunell
M (2003) CRYSTAL 2003 user's manual. University of Torino, Turin

Sun M, Rousse G, Abakumov AM, Van Tendeloo G, Sougrati MT, Courty M, Doublet ML, Tarascon JM (2014) An oxysulfate $\mathrm{Fe}_{2} \mathrm{O}\left(\mathrm{SO}_{4}\right)_{2}$ electrode for sustainable Li-based batteries. J Am Chem Soc 136:12658-12666

Swamy MSR, Prasad TP (1981) Thermal analysis of iron(II) sulphate heptahydrate in air. J Therm Anal 20:107-114

Swash P, Monhemius A (1994) Hydrothermal precipitation from aqueous solutions containing iron(III), arsenate and sulphate. Proceedings Hydrometallurgy '94. Chapman and Hall (eds), New York, pp. 177-190

Ventruti G, Scordari F, Schingaro E, Gualtieri AF, Meneghini C (2005) The order-disorder character of $\mathrm{FeOHSO}_{4}$ obtained from the thermal decomposition of metahohmannite, $\mathrm{Fe}^{+3}{ }_{2}\left[\mathrm{O}\left(\mathrm{SO}_{4}\right)_{2}\right] \cdot 4 \mathrm{H}_{2} \mathrm{O}$. Am Miner 90:679-686

Ventruti G, Della Ventura G, Scordari F, Susta U, Gualtieri AF (2014) In situ high-temperature XRD and FTIR investigation of hohmannite, a water-rich $\mathrm{Fe}$-sulfate, and its decomposition products. J Therm Anal Calorim. https://doi.org/10.1007/s10973-014-4305-2

Ventruti G, Della Ventura G, Orlando R, Scordari F (2015) Structure refinement, hydrogen-bond system and vibrational spectroscopy of hohmannite, $\mathrm{Fe}^{3+}{ }_{2}\left[\mathrm{O}\left(\mathrm{SO}_{4}\right)_{2}\right] \cdot 8 \mathrm{H}_{2} \mathrm{O}$. Miner Mag 79:11-24

Ventruti G, Della Ventura G, Corriero N, Malferrari D, Gualtieri AF, Susta U, Lacalamita M, Schingaro E (2016) In situ high-temperature $\mathrm{X}$-ray diffraction and spectroscopic study of fibroferrite, $\mathrm{FeOH}\left(\mathrm{SO}_{4}\right) \cdot 5 \mathrm{H}_{2} \mathrm{O}$. Phys Chem Miner. https://doi.org/10.1007/ s00269-016-0819-4

Ventruti G, Della Ventura G, Lacalamita M, Sbroscia M, Sodo A, Plaisier JR, Cinque G, Schingaro E (2018) Crystal-chemistry and vibrational spectroscopy of ferrinatrite, $\mathrm{Na}_{3}\left[\mathrm{Fe}\left(\mathrm{SO}_{4}\right)_{3}\right] \cdot 3 \mathrm{H}_{2} \mathrm{O}$, and its high-temperature decomposition. Phys Chem Miner. https:// doi.org/10.1007/s00269-018-0991-9

Werner PE, Eriksson L, Westdahl M (1985) TREOR: a semi-exhaustive trial-and-error powder indexing program for all symmetries. J Appl Crystal 18(1985):367-370

Xu J, Gao N, Tang Y, Deng Y, Sui M (2010) Perchlorate removal using granular activated carbon supported iron compounds: synthesis, characterization and reactivity. Environ Sci 22:1807-1813

Publisher's Note Springer Nature remains neutral with regard to jurisdictional claims in published maps and institutional affiliations. 